\title{
Public Sector's Innovativeness: Theoretical and Methodological Perplexities
}

DOI: 10.7595/management.fon.2018.0001

\begin{abstract}
Research question: This article considers the problems of measuring public sector innovation by asking the question whether and why interpretation of the achievements regarding the public sector innovativeness might be questionable. Motivation: The most recent literature on public sector innovation reveals two perspectives. One of them is assertion that the public sector suffers an innovation deficit, while the other claims that it is actually more innovative than a common credit. Insights in the results from recent large studies of measuring public sector innovation have shown very high rates of innovations, higher than in private sector (between $50 \%$ and $80 \%$ of respondents have recorded at least one type innovation during the period of two years). The lack of a uniquely, or at least dominant, attitude regarding the above-mentioned standpoints represents the basic inspiration for the actualization of this problem. Idea: The aim of the paper is twofold: 1) to offer an overview of three established theoretical attempts (assimilation, demarcation and integrative) dealing with public sector innovation, in order to present the evolution of the issue; 2) to prove that the inclination to more general over contextually specific understanding of innovation (and vice versa) has an impact both on its operationalization and on the interpretation of the achievements. Findings: In spite of the fact that theoretical considerations show noticeable detachment from assimilation perspective, empirical studies still copy this approach and the associated methodology. Surveys introduced subjectivity through arbitrary interpretation of the innovation concept, choice of research techniques and respondents and using of non-measurable goals as indicators of innovation outputs. Since this has affected and overrated their outcomes, we have found that empirical studies have not provided reliable depiction of the state of affairs regarding the PSI. Contribution: Having presented theoretical and methodological arguments why relying on the assimilation approach is neither the only nor even the most adequate way to answer the question whether the public sector is more innovative than the private one, we point to the necessity of using the other two approaches, particularly integrative one in order to find a coherent method of PSI measurement.
\end{abstract}

Key words: innovation, innovativeness, public sector, private sector, measuring

JEL classification: $\mathrm{O} 30, \mathrm{O} 35, \mathrm{O} 38, \mathrm{H} 83$

\section{Introduction}

Although the global competition imposed the necessity of continuous improvement of the innovative capacities of all market participants (Sørensen \& Torfing, 2012), apparent and rapidly increased focus on public sector innovation nowadays is conditioned by the following factors:

First, during the last ten years governments all over the world have been faced with considerable economic constraints. The private sector growth is not enough to haul European economies out of the recession, and governments at central and local levels increasingly view the public sector innovation as one of key means 
for solving pressing economic and social problems (Bekkers, Tummers \& Voorberg, 2013; Head \& Alford, 2013; Pollit, 2015).

Second, most western countries still rely on the New Public Management concept with the purpose of reforming the public sector. However, from the innovation perspective, it is a tool for rationalizing work processes rather than an attempt to produce innovative services or policies or create entirely new service systems (Hartley, Sørensen \& Torfing, 2013; Dunleavy \& Carrera, 2013)

Hence, governments at different levels are under pressure to enhance the public sector innovation to be able to deal with the problems which are beyond the realm of regular expectations. At the same time, they are obliged to do this under the circumstances when their resources are reduced, believing that the public sector innovation promises to deliver more with less. Is the public sector's innovativeness a substantial and rational institutional response to contemporary problems and challenges or a buzz word?

The purpose of this review article is twofold: a) to summarize the insights about the existing nonconformity between opposite strands through the systematization of recently published literature on the public sector innovation; b) to present theoretical and methodological arguments why interpretation of the achievements regarding public sector innovativeness might be questionable.

The structure of the paper is adapted to the stated goals and consists of the following sections. First, it offers an overview of three established theoretical attempts (assimilation, demarcation and integrative) dealing with the public sector innovation, in order to present the evolution of the issue. Second, the article considers the problems of memasuring the public sector innovation by commenting results of recent surveys and particularly by pointing to several conceptual and methodological shortcomings noticed in the reports. Finally, the paper concludes with remarks sublimating key insights, suggesting that the findings of empirical studies using the assimilation approach are not sufficiently reliable to answer the question of whether the public sector is more innovative than the private one.

\section{Challenges of Understanding Public Sector Innovation}

The public sector has always been innovated (at least occasionally if not continuously), and yet serious academic research of the public sector innovation (PSI) has (just) 30 years old tradition. During the eighties and the nineties of past century, owing to contributions made by a new public management paradigm, research was mostly directed to organizational changes in hierarchical structure of the public sector in terms of applying forms which have been already introduced in the private sector. It has claimed that these changes are a solution to a noticeable lack of the PSI. The balance has swung in favour of the PSI in the first decade of XXI century, becoming particularly attractive for researchers during the last ten years, when the number of articles devoted to this issue has increased 3 - 4 times at the annual level. In spite of the above mentioned, studies on innovation in the private sector are still prevailing (Rivera Leon, Simmonds \& Roman, 2012).

Although the literature dealing with the PSI tries to move away from the private sector Shumpeterian approaches towards discussions about innovation genuinely attributable to the public sector (i.e., innovations in public services, policies and governance: Hartley, 2005; Moore \& Hartley, 2008; Pollitt \& Hupe, 2011), three concepts have been established: assimilation, demarcation and integrative approaches (Morrar, 2014; Biege, Lay, Zanker \& Schmall, 2013; De Liso \& Vergori, 2017; Witell, Snyder, Gustafsson, Fombelle \& Kristensson, 2016). All three perspectives have something in common - they use the term "new" whenever they speak about innovativeness. However, "new" is a relative concept (Toivonen \& Touminen, 2009), since it incorporates radical as well as - something quite different - incremental innovation; also newness can mean new to the firm or to the society. That is why we need to make distinctions between these approaches.

The assimilation approach insists on the similarities between the private and the public sectors (both respect the logic of productivity and principles of efficiency), emphasizing the necessity of the introduction of liberalization and marketisation in the public sector in order to foster innovation and increase efficiency. Included into assimilation perspective is Bjork (2014), who explicitly uses terms like products, services, systems and processes, as well as Osborne and Brown (2014) who referred to products, processes, ideas or procedures and Giannopoulou, Gryszkiewicz \& Barlatier (2014), who did it implicitly by specifying product innovation as completely new or significantly improved "with respect to its characteristics or to its intended uses" (p. 25). Since the definition is transferred from the literature dealing with private innovations, the benefit of innovation (seen as the outcome) is measured in the same way - in economic value (exchange value) for firm developing. 
The proportion of papers representing the concept of assimilation today is relatively smaller due to the penetration of the other two concepts (Witell et al., 2016). However, it is still significant: a) being present in recent theoretical literature (Björk, 2014; Giannopoulou et al., 2014); b) dominating in practice, judging by the preferences of empirical studies devoted to the issue.

The demarcation perspective expanded assimilation definition of innovation, considering it insufficient for understanding innovativeness in the public sector since the PSI fundamentally differ in its character from the private ones. Having introduced a very important dichotomy (the firm and the customer one - Witell et al., 2016), they emphasize that the PSI should bring something new or some sort of change (again in outcome) for either the firm or the costumer. This concept is supported by authors like Jian and Wang (2013) who, apart from customer needs, speak of maintaining competitive advantage (this way they incorporate both use and exchange values), making only a partial departure from the assimilation approach, but also Salunke, Weerawardena \& McColl-Kennedy (2013) who spoke of the value for the firm and its clients. In general, they less often analyze the intended benefit of the innovation (just $17 \%$ of definitions use the term "value" - Wittel et al., 2016). And by pointing at the significance of use value, they leave aside the importance of exchange value. So does the integrative (synthesis) approach.

The synthesis viewpoint criticizes the previous research, trying to capture new as the degree of newness (Toivonen \& Touminen, 2009) as well as to define even broader - value-oriented - concept (Bennington \& Moore, 2011). This perspective includes, for example, Toivonen \& Touminen (2009) emphasizing the following things: renewal becomes an innovation if it is broadly new (and not only to its developer); only then does the renewal bring the benefit to the developer and provide added value to the customers. Also, it refers to Bekkers et al., (2013), understanding innovativeness as capacity of public organizations to learn and to implement radical changes.

Since arguing that the process of developing new services cannot be separated from implementation and value creation, Skalen, Gummerus, Koskull \& Magnusson (2014) understand innovativeness as creation of new value through the integration of practices and resources in new ways. This concept differs from the traditional perspective, because the benefit of innovation was observed through the lens of final user and his wellbeing - it provides substantial value to individuals and society (Lusch \& Nambisan, 2015). It is similar to the demarcation perspective: both of them understood innovation as something new for the firm which brings some change and use value for the customer. At the same time, the emphasis on the benefit (such as value) is higher in comparison with the demarcation approach. In fact, value proposition represents the platform for analysis; they speak about opening an innovative process (that is why the public sector organizations are suggested to maintain awareness of who is involved, because open innovation for them is not solely concerned with users or customers, but with wider public organizational goals and values and the need to create public, not only private value (Hernandez, Sanders \& Tuschke, 2015; Pahnke, McDonald, Wang \& Hallen, 2015)) and value co-creation with the help of users (Yan, Yang \& Dooley, 2017, Kankanhalli, Zuiderwijk \& Tayi, 2017); and also about an equal importance of the process of innovation and its outcome (Bekkers et al., 2013).

Demarcation and integrative approaches altogether emphasize that insufficient attention was paid to the evolutionary character of the changes described as PSI (Kattel, Cepilovs, Drechsler, Kalvet, Lember \& Tonurist, 2013). They claim that the scope of the PSI has changed, both in respect to what is understood by the PSI and where it occurs.

In fact, innovations are more ambiguous in the public than in the private sector: they need not be a physical artifact, but usually relate to change in relationships between providers of services and policies and their users. That is why it is suggested that innovation be defined as an idea, practice or object that being perceived as new, is brought into implementation (Hartley, 2008; Mulgan, 2009; Osborne \& Brown, 2011, 2014). This definition emphasizes that an innovation has to be considered as specific outcome in terms of newness, but also in terms of transformative learning process - its wider impact upon the organization, existing policy, sector or community (Bekkers et al., 2013).

Emphasizing the importance of the transformative learning process is nothing more than pointing to the fact that the understanding of contradictory issues is enhanced through cooperation and inter-organizational learning of several actors (Crespo, Griffith \& Lages, 2014). And these inter-organizational processes have just launched collaboration as a potential driver of innovation and established a reform wave known as new public governance (Hartley et al., 2013). Certainly, the insights that dominate the literature of the integrative approach in recent years, have contributed to this. They claim that the main driver of the PSI is to create public value, which is more than sheer efficiency (Bommert, 2010; Moore \& Hartley, 2008; Bekkers et al., 2013; Bao, Wang, Larsen \& Morgan, 2013). 
According to Bennington \& Moore (2011), public value has two dimensions: what the public values (which is different from what it wants or needs) and also what adds value to the public sphere. Apart from goods, services, rights, benefits and obligations that the public collectively value and which contribute to the public sphere, it refers to the rules and governance arrangements that impact the way in which a society conducts itself and therefore includes fairness, social justice, confidence and effectiveness.

Noticing of the importance of multiple values is also recognized in business literature. Since generating innovations, in accordance with an integrative approach, involves various external and internal stakeholders relying on diverse approaches (brainstorm, networking, open innovation), a new, flexible methodological tool is proposed (Value Creation Wheel or its light version - Value Creation Radar), adaptable to problems and context of implementation (Lages, 2016).

In essence, the central normative debate moves around the proper place of productivity among others public values and whether the technical (assimilation) approach is at all useful for the public sector. And although various camps of scholars sometimes advocate for one value or a set of values, most of them following the integrative approach agree that public managers predominantly have to realize multiple democratic values rather than base their tasks on productive rationality, as the assimilation standpoint insists on (Andrews \& Entwistle, 2013: Dunleavy \& Carrera, 2013).

Insights from literature indicate that understanding of the PSI has undergone substantial changes. Innovation understood only in general terms neglects that the very concept depends on the context where it is created and developed (i.e., what innovation is in one context need not be so in another one and vice versa). The evolution of PSI definitions (from unconditional identifying with private ones to focusing on public value) shows that we currently have a box of concepts consisting of different purposes, expectations, interests and outcomes, becoming even more difficult to be understood and handled. It is noticeable, too, that most of the changes were products of theoretical research, and very rarely arose as a result of a wider consultation process of interested participants (particularly the users of public sector innovation), on which the integrative approach insisted so much (CCIC, 2013). It is for this reason that claims that integrative concept is prevailing and replacing the other two (Carlborg, Kindstrom \& Kowalkowski, 2013) seem to be exaggerated. It is more certain that this approach is growing and gaining strength, and yet a number of articles adopting the other two perspectives has neither decreased nor disappeared (Witell et al., 2016).

If these three approaches are equally present and represented in the literature, why is the assimilation concept used in empirical studies? Is its choice objectively conditioned? Finally, can we unwittingly believe in the conclusions about the public sector innovativeness derived from the use of the assimilation approach? We will try to answer these questions in the next section.

\section{Measuring PSI - Theoretical and Methodological Reconsideration}

Surveys trying to measure the PSI have started to appear during the recent years. These studies mainly focused on public administration in developed economies. The most famous project among those covering the PSI in Europe are: Mepin Project (measuring innovativeness of the public sector in Nordic countries and Denmark; Bugge, Mortensen \& Bloch, 2011); NESTA (public innovation index dealing with local government and health in UK; Hughes, Moore \& Kataria, 2011); Innobarometer - surveys of the European Commission (European Commission, 2011; European Commission, 2012); Trends and Challenges in the PSI in Europe (Rivera Leon et al., 2012) and European PSI Scoreboard (the European Commission, 2013).

All these reports confirm that innovativeness of the public sector increased under pressures of citizens and businesses (due to their requests to improve and redesign old or introduce new services). This was not the result of innovation process opening (as the integrative approach expected it to be) since the above mentioned requirements did not represent the main drivers of innovations. In fact, they were either externally imposed or initiated internally by higher levels of management (Gemmell, Nolan \& Scobie, 2017; CCIC, 2013).

Still, insights in the results have shown very high rates of innovations, higher than in the private sector (between $50 \%$ and $80 \%$ of respondents have recorded at least one type innovation during the period of two years), which corresponds to theoretical claims about the public sector's responsiveness in regards of innovation fostering (Jain \& Jepensen, 2013). However, results presented in the surveys should be taken with a certain degree of caution. 
In the light of new theoretical developments in PSI literature, choosing the approach and consequently performance indicators meant to measure innovativeness turns out to be a conceptual problem above all, and then a technical one. As we have already mentioned, the focus of the analysis has shifted to a discussion of public values and compromises that should be made when choosing among multiple values (Bennington \& Moore, 2011). Resolving value conflict has particularly become popular in the public policy discourse because of the recognition that a volatile environment requires more than continuous improvement in existing policies, services and governance arrangements (Osborne \& Brown, 2014; Hartley, 2012).

This consequently imposed the need to distinguish productivity (i.e., efficiency, since these terms are used interchangeably in the literature) from other related concepts (effectiveness, value for money) when we are interested in the public sector performance (Dunleavy \& Carrera, 2013; Djellal \& Gallouj, 2010). However, effectiveness in the public sector is seen in theory as value creation to the citizen, which has no real maximum and thus is very hard to quantify (Kattel et al., 2013). In fact, as many of the effects may be not directly visible to individual service users, they cannot be singularly captured in individual satisfaction surveys (Kattel et al., 2013). Some authors argue that it is better to incorporate the fundamental values into the existing concept of efficiency. Their claims stem from the position that "public service efficiency is essentially a product of the proper functioning of democratic institutions" (Andrews and Entwistle, 2013, p. 258). These normative claims that call for a much broader efficiency definition in the context of the public sector (i.e., efficiency plus public values) would require a considerable broadening of the scope of measurement as well as assuming that outcomes and processes were incorporated into the efficiency calculations (Kattel et al., 2013). If measurement of public values and/or their harmonization is controversial, than measurement encompassing the efficiency and public values must be even more!

Therefore, there is an objective reason - lack of systemic framework for monitoring and measuring of previously mentioned changes in the PSI concept - why the researchers have opted for the assimilation perspective. In addition, the choice of this approach is argued by the claims that during the last two decades, the public sector has increasingly imported various performance instruments from the private sector (Bugge et al., 2011), making comparison of their innovativeness possible. It is worth noting (although not being the subject of our analysis) the attitudes which confront the above mentioned argument. As Casebourne (2014) claims, given the very different institutional environment and diverse incentives to innovate, simply transforming lesson from the market driven model into the public sector was unlikely to be an effective and functional approach for studying the actual state of affairs in the domain of the PSI. However, attitudes like this did not receive adequate support and / or were ignored.

Accordingly, empirical studies either explicitly (European Commission, 2011; Bugge et al., 2011) or implicitly (the others that we cited) identify innovativeness with perceived changes in the domain of services, products, business processes, organizational methods and ways of communication with users. This teoretical definition must also be followed by an operational one that translates the verbal meaning into a prescription for measurement to enable empirical research (Witell, et. al., 2016). That is why public sector productivity is mostly regarded as a technical term, which refers to the ratio of outputs to inputs in producing public services (Andrews \& Entwistle, 2013; Dunleavy \& Carrera 2013). This could be treated as measured fixation - when outcomes are difficult to measure, there is a natural tendency to use performance indicators based on measurable outputs (Pidd, 2005). Still, problems related to output valuation remain, so reports show no conformity regarding performance criteria. Quite the contrary - they include a wide variety of indicators (Dunleavy \& Carrera, 2013).

It turns out, therefore, that even if the assimilation approach was not questionable per se, the way of its application may contain several conceptual and methodological shortcomings noticed in the literature:

(1) Public sector organizations might interpret the concept of innovations arbitrarily, thus reporting a high level of innovativeness (Snyder, Witell, Gustafsson, Fombelle \& Kristensson, 2016). Some literature (CCIC, 2013) reveals that the typical idea of innovation in the public sector is rarely the implementation of completely new services or a delivery method. More often it is the adoption and adaption of technological innovations created by the private sector (for example, ICT), since technology influences the private sector innovations more directly than the public sector ones (Kattel, et al., 2013). This is consistent, as Witell et al., (2016) noticed, with early studies belonging to the assimilation approach claiming that service firms are passive recipients of technological innovation from other sectors (Witell et al., 2016). Obviously, it is still happening, just being interpreted differently.

The surveys often keep on reporting the electronic availability of public services, on-line platforms, administrative simplifications, E government (i.e., changes in service delivery initiated by the implementation 
of technology imported from the private sector) as the embodiment of high innovation in the public sector. In order to justify the results, only proper methodological remark is missing. They have come to it owing to convenient methodological explanation made by the EC (2013): speaking about initiatives that would be readily considered innovations inside the public administrations, they emphasized the shift to ICT tools as the example.

(2) Another issue concerns methodological issues of PSI measurement. Studies dominantly relied on interviews (MEPIN) and surveys (NESTA, Innobarometer), sometimes being supported by case studies or hard data. These research techniques are, as a rule, used to analyze attitudes and perceptions of the public sector managers. Subjectivity in analysis (made by the selection of techniques and respondents) is thus further enhanced (duplicated), since the use of the same research techniques on the sample of the private sector companies produced different comments and results regarding the public sector innovativeness (European Commission, 2012).

(3) Indicators measuring effects and impacts have encountered the same challenges in almost all surveys therefore suggesting using objectives as indicators for outputs (which is not in accordance even with restricted - technical definition of productivity). Goals (objectives) are often vague and call for success, but not determined precisely (Mihaiu, Opreana \& Cristescu, 2010). Thus, the reports contain the following type of findings: $76 \%$ of respondents argue that the public sector innovations (which were, in fact, the private sector innovations) enable better access to information, $71 \%$ of them think that customer satisfaction is more pronounced, and 61\% consider it facilitated (faster) service delivery (European Commission, 2011). These claims are normative, which is expected, as being based on soft data (opinions of those surveyed and interviewed). Also, they are disputable since opinion-based indicators do not measure the actual quality of public services, but changes in its level. This means that a good result is interpreted as a higher rate of change, which could be the result of a low-level starting point (Kattel et al., 2013).

If innovation is understand as a goal per se (as it actually is in the above mentioned example), then it contains something normative and is a priori comprehended (perceived) as a 'good thing' - a change impossible to oppose, always to be encouraged (Pollitt \& Hupe, 2011; Pollitt, 2015). Under these circumstances, any (even an incremental or ordinary) change can be understood, announced or reported as a semi-miracle innovation, which is a mode of transforming potential innovation into a rhetorical one (Potts \& Kastelle, 2010).

Surveys have, therefore, introduced subjectivity and other non-trivial challenges which certainly have affected their outcomes. This could be labelled as misrepresentation, since performance data are either misreported or distorted to create a good impression. It confirms claims that exaggerated respect for performance indicators and/or their inappropriate use (Pidd, 2005) can easily lead to virtual rather than real performance achievements.

Without any intention to underestimate the general importance of conducting large and comprehensive empirical studies, we find that due to the above-mentioned failures, their insights do not provide a sufficient amount of evidence that we have got the most accurate and reliable depiction of the state of affairs regarding the PSI.

Conslusion

In the literature dealing with the innovativeness of the public sector, there are three differentiated and established approaches: assimilation, demarcation and integrative ones. The assimilation approach insists on the similarities between the private and the public sector, innovation being perceived and measured in an identical way - in the economic (exchange) value for the organization. Owing to the demarcation approach the research focus has changed towards discussions about innovation genuinely attributable to the public sector - innovations in public services, policies and governance. That is why the benefit of innovation is viewed through the prism of the user, whereby the use value becomes a priority over the exchange value. The synthetic concept goes a step further, emphasizing the specificity of innovation not only as an outcome, but as a process that produces a wider impact and profound change in organizations and society.

Insights from literature, therefore, indicate that understanding of the PSI has undergone substantial changes. Speaking of theoretical consideration, its evolution shows a noticeable departure from the assimilation perspective. However, judging by empirical studies, its conceptualization still copies this approach.

During the recent years a number of large and comprehensive empirical studies have been carried out in order to measure the innovation of the public sector more accurately. It is noticeable that the starting point of these research remains a 
simplified notion of innovation compared to recent theoretical developments in the literature. The researchers actually have opted for the assimilation approach and the associated methodology, justifying their choice primarily with an objective limitation - a lack of different systemic framework that would incorporate the aforementioned evolutionary changes in the PSI. In addition, they are arguing that the public sector has increasingly imported various performance instruments from the private sector. However, it turns out that performance and efficiency measurements cannot be easily applied to the public sector: reports show no conformity and use a wide variety of indicators making the results mutually incomparable. Besides, surveys introduced subjectivity through arbitrary interpretation of innovation concept, choice of research techniques and respondents and using of non-measurable goals as indicators of innovation outputs. And it certainly has affected and overrated their outcomes. Since performance data are either misreported or distorted to create a good impression, we find that insights from empirical studies do not provide a sufficient amount of evidence that we have got the most accurate and reliable depiction of state of affairs regarding the PSI.

Finding a valid way to measure the PSI helps establish good (valuable) and bad (defect) aspects of its innovative capacity. A powerful framework for measuring the PSI provides a better insight into the performance of those belonging to the public sector, allows the government and general public to be aware of the extent to which progress has been made in the field of the PSI and also presents a basis for further improvement in this area. In the realization of such an idea it is necessary that an agreement be reached between opposite strands on a limited number of key indicators for which data would be gathered and serve as basis to make a deeper analysis with more valuable insights into innovative behavior of the public sector. Also, since PSI is a relatively underdeveloped topic, further research is expected to rely more on insights made by the demarcation and integrative concepts in order to offer more coherent methods of PSI measurement.

\section{Acknowledgments}

The research in this paper was conducted within Project No. 179065, „The Role of the State in the New Growth Model of the Serbian Economy", that is financially supported by the Ministry of Science and Technological Development of the Republic of Serbia.

\section{REFERENCES}

[1] Andrews, R., \& Entwistle, T. (2013). Four faces of public service efficiency. Public Management Review, 15(2), 246-264. DOI: 10.1080/14719037.2012.725760

[2] Bao, G., Wang, X., Larsen, G.L. \& Morgan, D. (2013). Beyond New Public Governance, Administration and Society, 45 (4), 443-467. Retrived from: http://journals.sagepub.com/doi/pdf/10.1177/0095399712464952

[3] Bekkers, V.J.J.M., Tummers, L.G. \& Voorberg, W.H. (2013). From public innovation to social innovation in public sector: A Literature Review of Relevant Drivers and Barriers, Paper presented on Erasmus University, Rotterdam.

[4] Bennington, J. \& Moore, M. (2011). Public value in complex and changing times. In J. Bennington \& M. Moore (Eds.), Public value: Theory and practice (pp. 1-30). Basingstoke: Palgrave Macmillan.

[5] Biege, S., Lay, G., Zanker, C., \& Schmall, T. (2013). Challenges of Meas-uring Service Productivity in Innovative, Knowledge-Intensive Business Services. The Service Industries Journal, 33 (3-4), 378-391. DOI: 10.1080/02642069.2013.747514

[6] Bjork, P. (2014). The DNA of tourism service innovation: A quadruple helix approach. Journal of the Knowledge Economy, 5 (1), 181 - 202. DOI: 10.1007/s13132-014-0183-x

[7] Bommert, B. (2010). Collaborative innovation in the public sector, International Public Management Review, 11(1), 15-33.

[8] Bugge, M., Mortensen, P. \& Bloch, C. (2011). Measuring public innovation in Nordic countries: Report on the Nordic pilot studies, analyses of methodology and results, MEPIN, NIFU, Oslo, Retrieved from: http://www.nifu.no/files/2012/11/NIFUrapport2011-40.pdf

[9] Carlborg, P., Kindström, D. \&. Kowalkowski, C. (2013). The evolution of service innovation research: A critical review and synthesis, The Service Industries Journal, 34 (5), 373-398. DOI: 10.1080/02642069.2013.780044

[10] Casebourne, J. (2014). Why motivation matters in public sector innovation, NESTA, Retrieved from: http://www.nesta.org.uk/sites/default/files/why_motivation_matters_in_public_sector_innovation.pdf

[11] CCIC (2013). Innovation in the public sector: State-of-the-art report, Applied research and communications fund, Sofia, Bulgaria. Retrieved from: http://www.ccic-project.eu/wpcontent/uploads/2013/10/CCIC-State-of-the-art-report-SotAreport.pdf

[12] Crespo, C. F. Griffith, D. A. \& Lages, L. F. (2014). The performance effects of vertical and horizontal subsidiary knowledge outflows in multinational corporations, International Business Review, 23 (5), 993 - 1007. DOI: 10.1016/j.ibusrev.2014.03.002 
[13] De Liso, N. \& Vergori, A. S. (2017), The Different Approaches to the Study of Innovation in Services in Europe and the USA, Metroeconomica, 68 (1), 121-146. DOI: 10.1111/meca.12129

[14] Djellal, F. \& Gallouj, F. (2010) The Innovation Gap and the Performance Gap in the Service Economies: A Problem for Public Policy. In F. Gallouj \& F. Djellal (Eds.), The Handbook of Innovation and Services (pp. 653-676). Cheltenham, UK: Edward Elgar Publishing.

[15] Dunleavy, P. \& Carrera, L. (2013). Growing the productivity of government services, Cheltenham, UK: Edward Elgar Publishing

[16] European Commission, (2011). Innobarometer 2010: Analytical report on innovation in public administration (Flash Eurobarometer 305), Brussels, Retrieved from: http://ec.europa.eu/public_opinion/flash/fl_305_en.pdf

[17] European Commission, (2012). Innobarometer 2011: Innovation in the public sector, it's perception and impact on business, (Flash Eurobarometer 343), Brussels, Retrieved from: http://ec.europa.eu/public_opinion/flash/fl_343_en.pdf

[18] European Commission, (2013). European public sector innovation scoreboard, Retrieved from: http://ec.europa.eu/enterprise/policies/innovation/files/epsis-2013_en.pdf

[19] Gemmell, N., Nolan, P. \& Scobie, G. (2017), Public sector productivity, Working Paper, Retrieved from: https://www.productivity.govt.nz/sites/default/files/170515\%20FINAL\%20Public\%20Sector\%20Productivi ty\%20School\%20Quality\%20Adjustment.pdf

[20] Giannopoulou, E., Gryszkiewicz, L. \& Barlatier, J-P. (2014). Creativity for service innovation: A practicebased perspective, Managing Service Quality: An International Journal, 24 (1), 23-44. DOI: 10.1108/MSQ-03-2013-0044

[21] Hartley, J, (2005). Innovation in governance and public services: Past and present, Public Money and Management Journal, 25 (1), 27-34.

[22] Hartley, J. (2008). Does innovation lead to improvement in public services? Lessons from the Beacon scheme in the UK. In S. Borins, (Ed.). Innovation in government: Research, recognition and replication (pp. 159-187).Washington: Brooking Institution Press.

[23] Hartley, J. (2012). Public value through innovation and improvement. In: J. Benington \& M. Moore (Eds), Public value: Theory and practice (pp. 171-184). Basingstoke: Palgrave Macmillan

[24] Hartley, J., Sørensen, E. \& Torfing, J. (2013). Collaborative Inovation: A viable Alternative to Market Competition and Organisational Entrepreneurship, Public Administration Review, 73 (6), 821-830 DOI: 10.1111/puar.12136

[25] Head, B. \& Alford, J. (2013). Wicked problems: Implications for Public Policy and Management. Administration and Society, 47 (6), 711-739 DOI: 10.1177/0095399713481601

[26] Hernandez, E. Sanders, G. \& Tuschke, A. (2015), Network defense: pruning, grafting, and closing to prevent leakage of strategic knowledge to rivals, Academy of Management Journal, 58 (4), 1233-1260.

[27] Hughes, A., Moore, K. \& Kataria, N. (2011). Innovation in public sector organisations: A pilot survey for measuring innovation across the public sector, NESTA Index Report, Retrieved from: http://www.nesta.org.uk/library/documents/Innovation_in_public_sector_organisations_v9.pdf

[28] Jain, A.K. \& Jeppesen, H.J. (2013). Knowledge management practices in a public sector organisation: the role of leaders' cognitive styles, Journal of Knowledge Management, 17 (3), 347-362. DOI: $10.1108 / \mathrm{JKM}-11-2012-0358$

[29] Jian, Z., \& Wang, C. (2013). The impacts of network competence, knowledge sharing on service innovation performance: Moderating role of relationship quality. Journal of Industrial Engineering and Management, 6 (1). DOI: 10.3296/JIM.659

[30] Kankanhalli, A. Zuiderwijk, A. \& Tayi, G. K. (2017). Open innovation in the public sector: A research agenda, Government Information Quarterly, 34 (1), 84 - 89. DOI: 10.1016/j.giq.2016.12.002

[31] Kattel, R. Cepilovs, A. Drechsler, W., Kalvet, T., Lember, V. \& Tõnurist P. (2013). Can we measure public sector innovation: Literature review, Retrieved from: http://lipse.org/userfiles/uploads/kattel\%20et\%20al\%20egpa\%20version.pdf

[32] Lages, L.F. (2016), VCW - Value Creation Wheel: Innovation, technology, business and society, Journal of Business Research, 69 (2), 4849 - 4855. DOI: 10.1016/j.jbusres.2016.04.042

[33] Lusch, R. F., \& Nambisan, S. (2015). Service innovation: A service-dominant logic perspective. MIS Quarterly, 39 (1), 155 - 176. Retrieved from: http://paulallen.ca/documents/2015/08/lusch-rf-and-snambisan-service-innovation-a-service-dominant-logic-perspective-2015.pdf

[34] Mihaiu, D. M. Opreana, A. \& Cristescu, M. P. (2010), Efficiency, effectiveness and performance of the public sector, Romanian Journal of Economic Forecasting, 4, 132 - 147. Retrieved from: http://www.ipe.ro/rjef/rjef4_10/rjef4_10_10.pdf

[35] Moore, M. \& Hartley, J. (2008). Innovation in governance, Public Management Review, 10(1), 3-20. DOI: $10.1080 / 14719030701763161$

[36] Morrar, R. (2014), Innovation in Services: A Literature Review, Technology Innovation Management Review, Retrieved from: https://timreview.ca/sites/default/files/article_PDF/Morrar_TIMReview_April2014.pdf 
[37] Mulgan, G. (2009). The art of public strategy: mobilizing power and knowledge for the common good, Oxford: Oxford University Press.

[38] Osborne, P. \& Brown, L. (2011). Innovation, public policy and public service delivery in UK: The word that would be king, Public Administration, 89(4), 1335-1350. DOI: 10.1111/j.1467-9299.2011.01932.x

[39] Osborne, P. \& Brown, L. (Eds.). (2014). Handbook of innovation and change in public sector service, London: SAGE.

[40] Pahnke, E.C. McDonald, R. Wang, D. \& Hallen, B. (2015). Exposed: venture capital, competitor ties and entrepreneurial innovation, Academy of Management Journal, 58 (5), 1334-1360. DOI: 10.5465/amj.2012.0777

[41] Pidd, M. (2005). Perversity in public services performance measurement, International Journal of Productivity and Performance Management, 54(5/6), 482-493.

[42] Pollitt, C. \& Hupe, P. (2011). Talking about government: The role of magic concept, Public Management Review, 13(5), 641-658. DOI: 10.1080/14719037.2010.532963

[43] Pollitt, C. (2015). Innovation and LIPSE: An interim assessment of innovative research project, Speech to LIPSE conference, Belgium. Retrieved from: http://lipse.org/userfiles/uploads/INNOVATION-LIPSEKeynote.pdf

[44] Potts, J. \& Kastelle, T. (2010). Public sector innovation research: what's next? Innovation: Organization \& Management, 12(2), 122-137. DOI: 10.5172/impp.12.2.122

[45] Rivera Leon, L., Simmonds, P. \& Roman, L. (2012). Trends and challenges in public sector innovation in Europe, Retrieved from: https://www.technopolis-group.com/wpcontent/uploads/2014/06/1447_INNOERATREND-2011-12.pdf

[46] Salunke, S., Weerawardena, J., \& McColl-Kennedy, J.R. (2013). Competing through service innovation: The role of bricolage and entrepreneurship in project-oriented Firms, Journal of Business Research, 66 (8), 1085 -1097. DOI: 10.1016/j.jbusres.2012.03.005

[47] Skalen, P., Gummerus, J., Koskull, C. \& Magnusson, P.R. (2014). Exploring value propositions and service innovation: A service-dominant logic study, Journal of the Academy of Marketing Science, 122. DOI: $10.1007 / \mathrm{s} 11747-013-0365-2$

[48] Snyder, H., Witell, L., Gustafsson, A., Fombelle, P. \& Kristensson, P. (2016). Identifying categories of service innovation: A review and synthesis of the literature, Journal of Business Research, 69 (7), 24012408. DOI: 10.1016/j.jbusres.2016.01.009

[49] Sørensen, E. \& Torfing, J. (2012), Collaborative Innovation in the Public Sector, The Innovation Journal: The Public Sector Innovation Journal, Volume 17(1), article 1. Retrieved from: https://www.innovation.cc/volumes-issues/intro_eva_sorensen_torfing_17v1i1.pdf

[50] Toivonen, M., \& Tuominen, T. (2009). Emergence of innovations in services. The Service Industries Journal, 29 (7), 887 - 902. DOI: 10.1080/02642060902749492

[51] Witell, L., Snyder, H., Gustafsson, A., Fombelle, P. \& Kristensson, P. (2016). Defining service innovation: A review and synthesis, Journal of Business Research, 69 (8), 2863-2872. DOI: 10.1016/j.jbusres.2015.12.055

[52] Yan, T., Yang, S. \& Dooley, K. (2017). A theory of supplier network-based innovation value, Journal of Purchasing and Supply Management, 23 (3), 153-162 DOI: 10.1016/j.pursup.2017.02.002

Received: 2017-07-28

Accepted: 2018-01-20

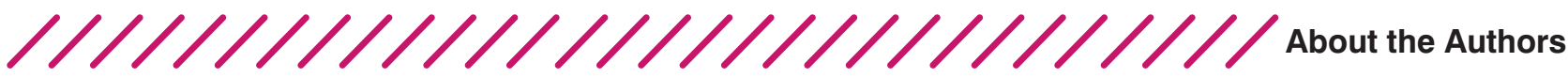

\section{Ljubinka Joksimović \\ University of Belgrade, Faculty of Economics, Serbia joka@ekof.bg.ac.rs}

Ljubinka Joksimovic is a full professor at the Faculty of Economics, University of Belgrade, at the Economic Theory and Analysis Department, where she teaches the following courses: Comparative Economic Systems, Economics of the European Union, Institutions and Economic Development, Competitiveness Policy, Theory and Analysis of the Public Choice. She is the author and co-author of numerous monographs, textbooks and papers in leading national and international scientific journals. The key areas of her scientific research interest are institutional economics, public policy and comparative economics.

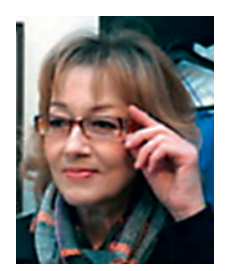




\section{Slavica Manić \\ University of Belgrade, Faculty of Economics, Serbia slavica@ekof.bg.ac.rs}

Slavica Manic is an associate professor at the Faculty of Economics, University of Belgrade, at the Economic Theory and Analysis Department. Her teaching commitments refer to the following courses: Methods of Economic Analysis, Competitiveness Policy and Economics of Transition. She has published (as author and co-author) numerous

papers in national and international scientific journals, some of them presented at relevant conferences. She participated in the realization of TEMPUS programme, CEEPUS activities and many national research projects. The main fields of her interest and research are economic development and methodology of economics.

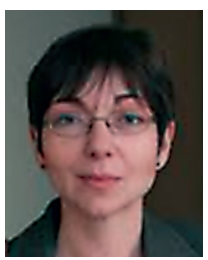

Danica Jović University of Belgrade, Faculty of Economics, Serbia dana@ekof.bg.ac.rs

Danica Jovic has graduated, earned the MSc degree and obtained the PhD degree from the Faculty of Economics, University of Belgrade, where she teaches Financial Accounting. She is an authorized accountant and member of the Association of Accountants and Auditors of Serbia. Danica Jović has published scientific and professional papers primarily in the areas of financial reporting and corporate governance. She participated in national and international conferences, as well as in the scientific projects of the Ministry of Science and Technology of the Republic of Serbia. The main fields of her interest are public sector reforms and their impact on evaluating performance and financial reporting of public sector entities. 